\title{
Good quality of life after more than a decade of living donor liver transplantation
}

\author{
Isabel Roldo NOGUEIRA', Julio Cezar Uili COELHO'1,2, Micheli Fortunato DOMINGOS², \\ Mônica Beatriz PAROLIN1', Jorge Eduardo Fouto MATIAS ${ }^{1,2}$, Alexandre Coutinho Teixeira de FREITAS ${ }^{1,2}$, \\ Eduardo Lopes MARTINS ${ }^{1}$ and Marco Aurélio Raeder da COSTA ${ }^{1,2}$
}

\begin{abstract}
Background - Receptors of living donor liver transplantation (LDLT) have higher rate of postoperative biliary and vascular complications that may reduce posttransplant quality of life (QOL) due to the need of invasive and repetitive treatments. Objective - The purpose of our study is to assess the various aspects of QOL of receptors undergoing LDLT after 10 years of transplantation and to identify potential factors that might be associated with impaired QOL. Methods - Data of all patients with more than 10 years of LDLT were retrospectively evaluated. Patients were interviewed through a quality of life questionnaire (SF-36). Results - From a total of 440 LT performed in 17 years (from September 1991 through December 2008), 78 patients underwent LDLT, of which 27 were alive and 25 answered completely the questionnaire. There were 17 (68\%) men and $8(32 \%)$ women, with a mean age of $38.6 \pm 18.5$ years at the time of transplantation and mean follow up time of $15.1 \pm 1.9$ years. The average MELD was $16.4 \pm 4.9$ and the main indication for LT was hepatic cirrhosis caused by hepatitis B virus (32\%). When compared to the general population, LDLT patients had lower mental health score $(66.4 \mathrm{vs} 74.5, P=0.0093)$ and higher vitality score $(87.8 \mathrm{vs} 71.9, P<0.001)$, functional aspects (94.6 vs 75.5, $P=0.002)$, social aspects ( 93 vs $83.9, P=0.005$ ), physical aspects ( 92 vs $77.5, P=0.006$ ), and emotional aspects ( 97.33 vs $81.7, P<0.001$ ). General health status ( 73.28 vs $70.2, P=0.074)$ and pain $(78.72$ vs $76.7, P=0.672)$ scores were similar in both groups. Conclusion - It is concluded that the various aspects LDLT recipients' QOF are similar to those of the general population more than a decade after the transplant, except for the mental health domain which is lower.
\end{abstract}

HEADINGS - Liver transplantation. Living donors. Liver cirrhosis. Quality of life.

\section{INTRODUCTION}

With the enormous success of liver transplantation (LT), both in survival and in quality of life (QOL), the number of liver transplants increased remarkably all over the world in the last decades. However, the demand for LT increased more rapidly than the number of liver donors, causing elevated mortality of patients on a long waiting list. The growing disparity between the number of liver transplant candidates and the supply of deceased donor organs has motivated the development of living donor liver transplantation (LDLT).

The first LDLT was performed by Raia et al. (1) $^{(1)}$ Brazil in 1989 to overcome the shortage of cadaveric organs for pediatric recipients. LDLT in children has become accepted worldwide in a few years and helped to reduce the mortality of patients on the waiting list. Right lobectomy for adult-to-adult LDLT, a more complex and challenging procedure, was successfully performed by Yamaoka et al. ${ }^{(2)}$ in Japan in 1994. Due to the risks of serious donor complications, including death, LDLT comprises a small percentage of total transplants in most countries. However, due to the limitation of cadaveric donation in some Asian countries, most LTs are performed with living donors. Although the results of LDLT are similar to those of deceased donor liver transplan- tation (DDLT), some complications are more common after LDLT, such as biliary stricture and fistula ${ }^{(3,4)}$. Post-transplant biliary complications may need prolonged endoscopic management, surgical treatment, and even retransplantation. This may reduce QOL after LT.

Several studies have evaluated the various aspects of QOL of donors of LDLT. However, only a few studies assessed the QOL of receptors of LDLT. Most of these studies are limited to patients undergoing LDLT in the short term. It has also not been determined whether the prolonged invasive treatment necessary to treat the higher rate of vascular and biliary complications following LDLT may decrease long-term $\mathrm{QOL}^{(3,4)}$. To the best of our knowledge there is no Brazilian study that evaluated the long-term QOL of patients who underwent LDLT. The objective of our study is to assess the various domains of QOL of receptors subjected to LDLT after 10 years and to identify potential factors that might be associated with impaired QOL.

\section{METHODS}

The present study was approved by the Ethical Committee of the Clinical Hospital of the Federal University of Paraná, Brazil (Protocol approval number CAAE 91362818.7.0000.0096). Data

Declared conflict of interest of all authors: none

Disclosure of funding: no funding received

${ }^{1}$ Serviço de Transplante Hepático, Hospital de Clínicas, Universidade Federal do Paraná, Curitiba, PR, Brasil. ${ }^{2}$ Serviço de Transplante Hepático, Hospital Nossa Senhora das Graças, Curitiba, PR, Brasil.

Corresponding author: Julio Cezar Uili Coelho. E-mail: coelhojcu@yahoo.com.br 
of all patients with more than 10 years of liver transplantation performed at the University Hospital of the Federal University of Paraná and Nossa Senhora das Graças Hospital, Curitiba, Brazil were retrospectively evaluated. All LT of the two hospitals were performed by the same transplantation team.

The following data were obtained from electronic medical records and study protocols: demographics, diagnosis, ChildPugh classification, Model for End-Stage Liver Disease (MELD), peritransplant clinical factors, transplant technique, immunosuppressive regimen, graft function, and complications. Before May 2006, when MELD was officially introduced in Brazil, this score was retrospectively calculated based on the exams performed on the day of the transplantation. LT was performed using standard surgical techniques. After LT, patients were placed on standard immunosuppressive protocol consisting of calcineurin inhibitor-based immunosuppressive therapy (tacrolimus or cyclosporine), azathioprine or mycophenolate mofetil, and prednisone.

\section{Patients' contact}

All alive patients who underwent LT in our two hospitals before December 31, 2008 were contacted by telephone, e-mail or during medical consultation. The study was completely explained to the patients. Strict confidentiality was assured, and it was explained that the transplant members would not have access to answers from any individual patients. All questions were duly answered and doubts dispelled.

A letter with explanations, the SF-36 questionnaire, and the consent form to participate of this study were given personally or sent to the patients by e-mail. A few patients opted to answer the questionnaire by phone or completed the questionnaire during routine medical consultation.

\section{Quality of Life Evaluation with the Short-Form 36 Questionnaire}

Subjective QOL was assessed through Short-Form 36 (SF-36). The aim of this questionnaire is to assess differences of various domains of QOL (physical, functional, emotional and social aspects) between the general population and patients affected by a specific condition. This health survey is the most frequently employed QOL method to evaluate liver transplant recipients ${ }^{(5,6)}$. SF-36 is a generic, self-rated health survey designed to compare health status across diverse populations. This questionnaire is an internationally accepted general QOL survey validated by several authors, including for application in Brazilian population ${ }^{(7,8)}$. It offers broad-spectrum questions applicable to a variety of patient groups and enables comparison between different populations.

The questionnaire includes 36 questions divided into eight subscales or domains named general health, physical functioning, physical role functioning, body pain, mental health, emotional role functioning, social functioning, and vitality, as well as aggregate scores for physical and mental health. For each question, a score was attributed. Calculation was performed according to the SF-36 questionnaire protocol, composed by the data weighting phase and raw scale calculation phase 2, with scores ranging from 0 to 100. Higher scores indicate better health status. Another important advantage of the SF-36 questionnaire is the versatility of its application by self-filling, telephone, computer or personal interview for individuals above 14 years of age $\mathrm{e}^{(6,9,10)}$. The time to answer all questions is usually 5 to 10 minutes $^{(9,10)}$.
In order to evaluate de QOL, the data obtained from the questionnaire answers of our patients was compared with those determined previously by Laguardia et al. ${ }^{(9)}$ from the general Brazilian population and Cruz et al. ${ }^{(10)}$ for the population of the south Brazilian region. The data from the study of these researchers was obtained from the general Brazilian population constituted of 12,423 randomly selected Brazilian men and women aged 18 years old or more from urban and rural areas of all five Brazilian regions who participated from the SF-36 questionnaire (Social Dimensions of Inequalities Study).

\section{Statistical analysis}

Values were expressed as mean \pm SD (standard deviation) and median (minimum and maximum values). Qualitative variables were represented by absolute frequency (n) and relative frequency ( $\%)$.

Nonparametric approaches were used since there was no normal distribution of the eight domains for any of the strata of the three grouping variables by the Kolmogorov-Smirnov test.

The Mann-Whitney nonparametric test was applied to evaluate the eight QOL domains provided by the SF-36 and their relation to the dichotomized MELD, dichotomized age $(\leq 50$ and $>50$ years), gender and presence or absence of acute complications. To evaluate the QOL with Child's classification, the Kruskal-Wallis nonparametric test was used. To analyze whether the mean scores of each of the eight SF-36 domains of the patients evaluated in the present study are different from those presented in previous studies of general population and population in the South of Brazil, the Student's $t$-test for one sample was used. The data were analyzed using the statistical software SPSS 22.0 considering a significance level of $5 \%(P$ value $\leq 0.05)$.

\section{RESULTS}

Of a total of 440 LT performed in the period of September of 1991 through December of 2008, there were 79 LDLT done in 78 patients. One of the LDLT was subjected to retransplantation. It was excluded from the study 342 patients (361 transplants, including 19 retransplants) who were subjected to deceased donor LT.

Of all patients who underwent LDLT, 27 (34.6\%) were alive on December 31, 2018. Two of these patients had no follow-up in our hospital and were excluded from the study. The remaining 25 patients opted to participate of the research and responded all questions of the questionnaire of the QOL completely. These 25 patients were subjected to the study.

\section{Clinical and epidemiological characteristics}

Clinical and epidemiological characteristics of the 25 patients who have participated of the study are shown in TABLE 1 . The mean follow-up time was $15.1 \pm 1.9$ years (range, 12 to 19 years). There were $17(68 \%)$ men and $8(32 \%)$ women, with a mean age of $38.6 \pm 18.5$ years (range, 0 to 60 years) at the time of transplantation and 53.6 \pm 17.5 years (range, 19 to 75 years) at the time of study analysis.

Almost all patients were class $B(n=16 ; 64 \%)$ or class $C(n=7$; $28 \%$ ) of the classification of Child-Pugh. Only $2(8 \%)$ patients were class A.

The MELD varied from 4 to 27 , with a mean of $16.4 \pm 4.9$. Most patients $(n=13 ; 52 \%)$ had MELD in the range of $10-17$. For this purpose, additional points were not added to the MELD score of patients with associated hepatocellular carcinoma. 
TABLE 1. Epidemiological, clinical characteristics, etiology of liver disease and SF-36 domains.

\begin{tabular}{|c|c|}
\hline Characteristics & Patients \\
\hline Number & 25 \\
\hline \multicolumn{2}{|c|}{ Age at the time of transplantation (year) } \\
\hline Mean \pm SD & $38.6 \pm 18.5$ \\
\hline Median (min-max) & $46(0-60)$ \\
\hline \multicolumn{2}{|c|}{ Age at the time of study analysis (year) } \\
\hline Mean \pm SD & $53.6 \pm 17.5$ \\
\hline Median (min-max) & $61(19-75)$ \\
\hline \multicolumn{2}{|l|}{ Gender $[\mathrm{n}(\%)]$} \\
\hline Male & $17(68)$ \\
\hline Female & $8(32)$ \\
\hline \multicolumn{2}{|c|}{ ICU time at the time of transplantation (days)* } \\
\hline Mean \pm SD & $8.8 \pm 16.6$ \\
\hline Median (min-max) & $3(1-80)$ \\
\hline \multicolumn{2}{|c|}{ Hospital time at the time of transplantation (days)* } \\
\hline Mean \pm SD & $23.2 \pm 21.6$ \\
\hline Median (min-max) & $16.5(9-110)$ \\
\hline \multicolumn{2}{|l|}{ Follow-up time (year) } \\
\hline Mean \pm SD & $15.1 \pm 1.9$ \\
\hline Median (min-max) & $15(12-19)$ \\
\hline \multicolumn{2}{|l|}{ Child-Pugh Classification [n (\%)] } \\
\hline A & $2(8)$ \\
\hline $\mathrm{B}$ & $16(64)$ \\
\hline $\mathrm{C}$ & $7(28)$ \\
\hline \multicolumn{2}{|l|}{ MELD Score $[\mathrm{n}(\%)]$} \\
\hline$<10$ & $2(8)$ \\
\hline $10-17$ & $15(60)$ \\
\hline $18-22$ & $4(16)$ \\
\hline$>23$ & $4(16)$ \\
\hline \multicolumn{2}{|l|}{ Etiology $[\mathrm{n}(\%)]$} \\
\hline Hepatitis B virus & $8(32)$ \\
\hline Alcoholic cirrhosis & $4(16)$ \\
\hline Autoimmune hepatitis & $3(12)$ \\
\hline Primary sclerosis sholangitis & $3(12)$ \\
\hline Hepatitis $C$ virus & $3(12)$ \\
\hline Biliary atresia & $2(8)$ \\
\hline Type 1 glycogenesis & $1(4)$ \\
\hline Cryptogenic cirrhosis & $1(4)$ \\
\hline
\end{tabular}

SD: standard deviation; MELD: Model for End-Stage Liver Disease. *Total n=24.

The main indications for LT were hepatic cirrhosis caused by hepatitis $B$ virus (HBV) $(n=8)$, alcoholic cirrhosis $(n=4)$, autoimmune hepatitis $(n=3)$, primary sclerosis cholangitis $(n=3)$ and hepatitis $\mathrm{C}$ virus (HCV) $(\mathrm{n}=3)$. All patients with alcoholic cirrhosis had at least 6 months of alcohol abstinence before the LT.

Of the 25 patients analyzed, $18(72 \%)$ of them had one or more complications of cirrhosis. The main liver complications recorded before the LT were ascites in $13(52 \%)$ patients, hepatic encephalopathy in $7(28 \%)$ patients and upper gastrointestinal hemorrhage in $7(28 \%)$ patients. Other pre-LT complications were jaundice, spontaneous bacterial peritonitis, hepatorenal syndrome, and osteoporosis, one of each.

\section{Postoperative complications}

Fourteen patients $(54 \%)$ had early postoperative complications. Early postoperative complication was defined as any clinical and surgical complication that occurred within 30 days after LT. The main complication was biliary fistula, which occurred in $6(24 \%)$ patients. Other complications are shown in TABLE 2. Four patients were subjected to abdominal reoperation within 30 days after LT, two for abdominal lavage and biliary drainage due to biliary fistula and two for deceased liver retransplantation due to hepatic artery thrombosis.

TABLE 2. Early and late postoperative complications.

\begin{tabular}{lc}
\hline Characteristics & Patients \\
\hline Early postoperative complications [n (\%) ]* & $6(24)$ \\
Biliary fistula & $2(8)$ \\
Hepatic artery thrombosis & $1(4)$ \\
Septic shock & $1(4)$ \\
Pleural effusion & $1(4)$ \\
Parenchymal ischemia & $1(4)$ \\
Pyelonephritis in kidney graft & $1(4)$ \\
CMV infection & $1(4)$ \\
Resistant gastroenteritis & \\
Late postoperative complications [n (\%)]* & $9(36)$ \\
Biliary stricture & $4(16)$ \\
Recurrent autoimmune hepatitis & $3(12)$ \\
Hepatitis B virus reactivation & $2(8)$ \\
Hepatitis C virus reactivation & $1(4)$ \\
Alcohol relapse & $1(4)$ \\
CMV infection & $1(4)$ \\
Perfusional graft disorder &
\end{tabular}

After 30 days of LT to date, $10(40 \%)$ patients did not present any chronic complications. Among the others $15(60 \%)$ patients, the main complication was biliary stricture which occurred in $9(36 \%)$ patients. Other complications are shown in TABLE 2.

\section{Quality of life evaluation}

The QOL data obtained from the questionnaire answers by our patients is shown in TABLE 3. The domain scores of LDLT patients varied from 66.4 (mental health) to 97.33 (emotional aspect limitations). These data were expressed as average with $95 \%$ CI.

LDLT patients had lower mental health $(\mathrm{MH})$ score than the general Brazilian population [66.4 (60.5-72.3, 95\% CI) vs 74.5, $P=0.009]$ (TABLE 3$)$. On the contrary, vitality (V) [87.8 (81.9-93.7, $95 \% \mathrm{CI}$ ) vs $71.9, P<0.001]$, functional aspects (FA) [94.6 (91.8-97.4, $95 \% \mathrm{CI}$ ) vs $75.5, P=0.002]$, social aspects (SA) [93 (86.8-99.2, 95\% CI) vs 83.9, $P=0.005]$, physical aspects (PA) [92 $(82.3-100,95 \%$ CI) vs 77.5, $P=0.006]$, emotional aspects (EA) [97.33 (93.5-100, $95 \% \mathrm{CI}$ ) vs $81.7, P<0.001$ ] scores were higher in LDLT patients than in the general population. General health status $(\mathrm{GH})[73.28$ $(69.9-76.7,95 \% \mathrm{CI})$ vs 70.2, $P=0.074]$ and pain $(\mathrm{P})[78.72(69-88.4$, $95 \% \mathrm{CI}$ ) vs $76.7, P=0.672]$ scores were similar in the two groups.

When compared to the population of Southern Brazil, LDLT patients had also lower mental health score [66.4 (60.5-72.3, 95\% CI) vs 73.82, $P=0.016]$ (TABLE 3 ). However, LDLT recipients had better quality of life in almost all the domains, except for the general health status [73.28 (69.9-76.7, 95\% CI) vs 71.1, $P=0.199]$, which there was no difference between the two groups. 
TABLE 3. Comparation of mean scores of QOL between LDLT Patients vs Brazil's population vs South Brazil's population.

\begin{tabular}{|c|c|c|c|c|c|}
\hline QOL & $\begin{array}{c}\text { LDLT } \\
(\mathrm{n}=25) \text { mean }\end{array}$ & $\begin{array}{c}\text { Brazil's population } \\
(\mathrm{n}=12,423) \text { mean }\end{array}$ & $\begin{array}{c}P \text { value } \\
\text { Student t test* }\end{array}$ & $\begin{array}{l}\text { South Brazil population } \\
(\mathrm{n}=755) \text { mean }\end{array}$ & $\begin{array}{c}P \text { value } \\
\text { Student } t \text { test }\end{array}$ \\
\hline Mental health & 66.4 & 74.5 & 0.009 & 73.82 & 0.016 \\
\hline General health status & 73.28 & 70.2 & 0.074 & 71.1 & 0.199 \\
\hline Pain & 78.72 & 76.7 & 0.672 & 67.53 & 0.026 \\
\hline Functional aspects & 94.6 & 75.5 & 0.002 & 82.45 & 0.005 \\
\hline Physical aspects & 92 & 77.5 & 0.006 & 74.73 & 0.001 \\
\hline Emotional aspects & 97.33 & 81.7 & $<0.001$ & 70.02 & $<0.001$ \\
\hline
\end{tabular}

QOL: quality of life; LDLT: liver donor liver transplantation. Numbers were expressed in mean. *Statistically significant $(P<0.05)$.

TABLE 4 illustrated that there was no difference between patients with MELD $\leq 15$ and those with MELD $>15$ in any of eight domains of QOL assessed. There was also no difference when patients were divided according to the Child classification, gender or age (TABLE 4). Mental health aspects score was lower for patient with acute complications $(58.91 \pm 18.51$ vs $72.29 \pm 5.54, P=0.033)$. There was no other difference between the groups.

\section{DISCUSSION}

Advances in intensive care medicine, immunosuppression, perioperative management, and surgical techniques allowed impressive improvement in patient survival after LT in the last decades. Presently, LT 5- and 10-year survival rate is about $75 \%$ and $70 \%$, respectively. Several studies have also documented excellent QOL after LT, with most patients returning to normal life ${ }^{(11-14)}$. However, there are only a few studies that assess QOL after LDLT and almost all these studies are limited to the QOL of the donor ${ }^{(15-18)}$. Receptors of LDLT have some important different aspects from those of DDLT that justify a distinct evaluation ${ }^{(19)}$.

Receptors of LDLT have higher rate of postoperative biliary and vascular complications ${ }^{(20,21)}$. Biliary technical complications are common following reconstitution of one to three tiny bile ducts from partial liver grafts obtained from living donors ${ }^{(22)}$. The rate of vascular complications, mainly hepatic artery thrombosis, is also higher in receptors of LDLT due to small hepatic artery of a hepatic lobe rather than a large artery from the entire liver. In addition to the higher rate of these complications, their complexity is expressive. They are associated with increase hospital stay, cost, morbidity and mortality. Quality of life is reduced due to need of repeated admissions and invasive treatments, such as percutaneous, endoscopic and surgical procedures to treat biliary and vascular complications. Retransplantation rate is also higher in these receptors ${ }^{(20)}$.

Our study evaluated the QOL of recipients of LDLT with more than 10 years of successful transplantation. Our mean follow-up time was 15 years. The survival rate of $34,6 \%$ observed in our study is lower than that of most American, European, and Japanese hospitals. Presently, 10-year survival rate of patients subjected to LDLT in the United States and Europe is about 50 to $60 \%$. In Japan, this rate is even higher, about $70 \%{ }^{(23)}$. Our lower patient survival may be possibly due to several medical limitations of developing countries, like Brazil, mainly scarcity of appropriate hospital resources and patients' economic and cultural differences.
The goal of LT is not only to obtain long survival rate, but also to achieve an excellent QOL in all aspects, including physical, psychological, and social domains. With the significant improvement in survival of patients undergoing LT in the last decades, several transplantation centers and government and insurance health organizations have begun to focus attention on $\mathrm{QOL}$ after $\mathrm{LT}^{(5,24,25)}$. The evaluation and applications of QOL after LT have expanded dramatically in the last years ${ }^{(11,12)}$. Studies with different follow-up and questionnaires have been used to assess QOL following LT $^{(6,24,25)}$. QOL assessment should consider both objective data obtained by the medical team and patient's opinions of their health, reflecting how they really feel, and how much their disease affects their way of life.

The World Health Organization Committee for QOL defined that QOL is a "multidimensional construct that is affected by physical health, psychological health, functional status, social relationships, personal beliefs"(26). The method of QOL evaluation used in our study was the SF-36, which has been validated in several countries. It is the most frequently method employed to evaluate QOL of liver transplant recipients. This questionnaire assesses eight domains on general health, functional capacity, physical aspects, bodily pain, mental health, emotional role functioning, social functioning, and vitality.

The few publications on QOL after LDLT are limited either to one or few QOL domains assessed or to patients with follow-up less than 5 years after $\mathrm{LT}^{(5,24,25)}$. Our study assessed all eight QOL domains of LDLT recipients with more than 10 years of successful transplantation.

Our study showed that recipients of LDLT with more than 10 years of successful transplantation had good QOL rates in all domains. When compared with the QOL of the general Brazilian population and the population of the Southern region of Brazil, LDLT recipients had better or similar QOL in all domains, except for mental health. Mental health domain was lower in transplanted patients than in the general Brazilian population or in the population of the Southern region of the country.

Several studies demonstrated that socioeconomic status, such as marital status, education level, social support, income, profession and employment are crucial factors that influence QOL after $\mathrm{LT}^{(6,27-}$ ${ }^{30)}$. Since Brazil is a large country with enormous socioeconomic and cultural differences between the Brazilian regions, we considered that was is important to compare QOL of LDLT patients not only with that of the general population, but also with that of the South Brazilian region, where our hospitals are located. 
TABLE 4. QOL after 10 years of LDLT According to MELD ( $\leq 15$ and $>15$ ), Child (A, B or C), Age ( $\leq 50$ and $>50$ years), Gender and Occurrence of Acute Complications.

\begin{tabular}{|c|c|c|c|c|c|c|c|c|c|}
\hline QOL & & EA & PA & SA & FA & $\mathbf{P}$ & $\mathrm{GH}$ & MH & VT \\
\hline \multicolumn{10}{|l|}{ MELD } \\
\hline \multirow{2}{*}{$\begin{array}{l}\leq 15 \\
(n=11)\end{array}$} & Mean \pm SD & $96.96 \pm 10.07$ & $100 \pm 0$ & $89.77 \pm 16.6$ & $95.91 \pm 4.37$ & $76.55 \pm 21.77$ & $70.18 \pm 7.03$ & $65.82 \pm 16.53$ & $87.27 \pm 12.92$ \\
\hline & $\begin{array}{c}\text { Median } \\
(\min -\max )\end{array}$ & $100(66.6-100)$ & $100(0-100)$ & $100(50-100)$ & $95(90-100)$ & $72(40-100)$ & $67(60-80)$ & $72(20-76)$ & $90(55-100)$ \\
\hline \multirow{3}{*}{$\begin{array}{l}>15 \\
(n=14)\end{array}$} & Mean \pm SD & $97.61 \pm 893$ & $85.71 \pm 30.56$ & $95.54 \pm 13.52$ & $93.57 \pm 8.19$ & $80.43 \pm 25.53$ & $75.71 \pm 8.56$ & $66.86 \pm 12.98$ & $88.21 \pm 15.64$ \\
\hline & $\begin{array}{c}\text { Median } \\
(\min -\max )\end{array}$ & $100(66.6-100)$ & $100(0-100)$ & $100(50-100)$ & $95(75-100)$ & $92(30-100)$ & $80(57-87)$ & $72(32-76)$ & $92.5(45-100)$ \\
\hline & $\begin{array}{c}P \text { Mann-Whitney } \\
\text { test* }\end{array}$ & 0.936 & 0.373 & 0.373 & 0.727 & 0.536 & 0.075 & 0.979 & 0.572 \\
\hline \multicolumn{10}{|l|}{ Child } \\
\hline \multirow[b]{2}{*}{$A(n=2)$} & Mean \pm SD & $100 \pm 0$ & $100 \pm 0$ & $100 \pm 0$ & $95 \pm 7.07$ & $92 \pm 11.31$ & $63.5 \pm 4.95$ & $64 \pm 5.66$ & $87.5 \pm 10.61$ \\
\hline & $\begin{array}{c}\text { Median } \\
(\min -\max )\end{array}$ & $100(100-100)$ & $100(100-100)$ & $100(100-100)$ & $95(90-100)$ & $92(84-100)$ & $63.5(60-67)$ & $64(60-68)$ & $87.5(80-95)$ \\
\hline \multirow{3}{*}{$\begin{array}{l}\text { B } \\
(n=16)\end{array}$} & Mean \pm SD & $91.91 \pm 8.37$ & $90.63 \pm 27.2$ & $89.84 \pm 17.81$ & $94.06 \pm 6.88$ & $74.75 \pm 23.57$ & $74 \pm 6.79$ & $65 \pm 16.94$ & $86.88 \pm 16.21$ \\
\hline & $\begin{array}{c}\text { Median } \\
(\min -\max )\end{array}$ & $100(66.6-100)$ & $100(0-100)$ & $100(50-100)$ & $95(75-100)$ & $72(40-100)$ & $75(62-85)$ & $72(20-76)$ & $92.5(45-100)$ \\
\hline & Mean \pm SD & $95.23 \pm 12.62$ & $92.86 \pm 18.9$ & $98.21 \pm 4.72$ & $95.71 \pm 7.32$ & $84 \pm 25.95$ & $74.43 \pm 10.88$ & $70.29 \pm 8.6$ & $90 \pm 11.18$ \\
\hline \multirow[t]{2}{*}{$C(n=7)$} & $\begin{array}{c}\text { Median } \\
(\min -\max )\end{array}$ & $100(66.6-100)$ & $100(50-100)$ & $100(87.5-100)$ & $100(80-100)$ & $100(30-100)$ & $80(57-87)$ & $76(56-76)$ & $90(70-100)$ \\
\hline & $\begin{array}{c}P \text { Kruskal-Wallis } \\
\text { test } *\end{array}$ & 0.744 & 0.866 & 0.433 & 0.703 & 0.445 & 0.230 & 0.496 & 0.806 \\
\hline \multicolumn{10}{|l|}{ Sex } \\
\hline \multirow{2}{*}{$\begin{array}{l}\text { Men } \\
(n=17)\end{array}$} & Mean \pm SD & $98.04 \pm 8.10$ & $91.18 \pm 26.43$ & $95.59 \pm 12.45$ & $94.12 \pm 5.93$ & $80.59 \pm 24.14$ & $72.59 \pm 8.6$ & $68.71 \pm 11.68$ & $87.94 \pm 13.81$ \\
\hline & $\begin{array}{c}\text { Median } \\
(\min -\max )\end{array}$ & $100(66.6-100)$ & $100(0-100)$ & $100(50-100)$ & $95(80-100)$ & $84(30-100)$ & $75(57-87)$ & $76(32-76)$ & $90(45-100)$ \\
\hline \multirow{3}{*}{$\begin{array}{l}\text { Women } \\
(\mathrm{n}=8)\end{array}$} & Mean \pm SD & $95.83 \pm 11.81$ & $93.75 \pm 17.68$ & $87.5 \pm 18.9$ & $95.63 \pm 8.63$ & $74.75 \pm 23.28$ & $74.75 \pm 7.8$ & $61.5 \pm 18.75$ & $87.5 \pm 16.04$ \\
\hline & $\begin{array}{c}\text { Median } \\
(\min -\max )\end{array}$ & $100(66.6-100)$ & $100(50-100)$ & $100(50-100)$ & $100(75-100)$ & $72(41-100)$ & $76(62-85)$ & $68(20-76)$ & $92.5(55-100)$ \\
\hline & $\begin{array}{c}P \text { Mann-Whitney } \\
\text { test* }\end{array}$ & 0.798 & 1.0 & 0.374 & 0.288 & 0.549 & 0.549 & 0.238 & 0.887 \\
\hline \multicolumn{10}{|c|}{ Age at the time of transplantation } \\
\hline \multirow{2}{*}{$\begin{array}{l}\leq 50 \\
(n=17)\end{array}$} & Mean \pm SD & $98.04 \pm 8.10$ & $91.18 \pm 26.43$ & $90.44 \pm 17.42$ & $95.88 \pm 6.9$ & $77.59 \pm 23.36$ & $74.53 \pm 8.02$ & $65.88 \pm 16.62$ & $88.53 \pm 16.28$ \\
\hline & $\begin{array}{c}\text { Median } \\
(\min -\max )\end{array}$ & $100(66.6-100)$ & $100(0-100)$ & $100(50-100)$ & $100(75-100)$ & $84(40-100)$ & $75(60-87)$ & $72(20-76)$ & $95(45-100)$ \\
\hline \multirow{3}{*}{$\begin{array}{l}>50 \\
(\mathrm{n}=8)\end{array}$} & Mean $\pm \mathrm{SD}$ & $95.83 \pm 11.81$ & $93.75 \pm 17.68$ & $98.44 \pm 4.42$ & $91.88 \pm 5.94$ & $81.13 \pm 25.36$ & $70.63 \pm 8.63$ & $67.5 \pm 8.4$ & $86.25 \pm 9.16$ \\
\hline & $\begin{array}{c}\text { Median } \\
(\min -\max )\end{array}$ & $100(66.6-100)$ & $100(50-100)$ & $100(87.5-100)$ & $92.5(80-100)$ & $92(30-100)$ & $71(57-80)$ & $68(56-76)$ & $85(70-100)$ \\
\hline & $\begin{array}{c}P \text { Mann-Whitney } \\
\text { test* }\end{array}$ & 0.798 & 1.0 & 0.440 & 0.057 & 0.711 & 0.315 & 0.711 & 0.262 \\
\hline \multicolumn{10}{|c|}{ Acute complications } \\
\hline \multirow{2}{*}{$\begin{array}{l}\text { Yes } \\
(n=11)\end{array}$} & Mean \pm SD & $96.96 \pm 10.07$ & $95.45 \pm 15.06$ & $89.77 \pm 20.01$ & $95 \pm 7.07$ & $83.73 \pm 22.86$ & $70.91 \pm 9.6$ & $58.91 \pm 18.51$ & $84.09 \pm 19.60$ \\
\hline & $\begin{array}{c}\text { Median } \\
(\min -\max )\end{array}$ & $100(66.6-100)$ & $100(50-100)$ & $100(50-100)$ & $100(80-100)$ & $78(40-100)$ & $75(57-85)$ & $60(20-76)$ & $95(45-100)$ \\
\hline \multirow{3}{*}{$\begin{array}{l}\text { No } \\
(n=14)\end{array}$} & Mean \pm SD & $96.61 \pm 8.93$ & $89.29 \pm 28.95$ & $95.54 \pm 9.31$ & $94.29 \pm 6.75$ & $74.79 \pm 24.16$ & $75.14 \pm 6.81$ & $72.29 \pm 5.54$ & $90.71 \pm 7.56$ \\
\hline & $\begin{array}{c}\text { Median } \\
(\min -\max )\end{array}$ & $100(66.6-100)$ & $100(0-100)$ & $100(75-100)$ & $100(75-100)$ & $78(30-100)$ & $77.5(65-87)$ & $76(60-76)$ & $90(80-100)$ \\
\hline & $\begin{array}{c}P \text { Mann-Whitney } \\
\text { test* }\end{array}$ & 0.936 & 0.809 & 0.727 & 0.609 & 0.373 & 0.244 & 0.033 & 0.767 \\
\hline
\end{tabular}

VT: vitality; MH: mental health; GH: general health status; P: pain; FA: functional aspects; SA: social aspects; PA: physical aspects; EA: emotional aspects. Numbers were expressed in mean ${ }_{ \pm} \mathrm{SD}$, median (min-max). *Statistically significant $(P<0.05)$. 
Similar to our findings, some other studies have documented a significant QOL improvement of recipients of LDLT. El-Meteini et al. have shown improvement in all eight domains evaluated six months after LT by the Short-Form 36 of all 35 patients subjected to LDLT in Egypt $^{(5)}$. Kawagishi et al. have demonstrated that most children who underwent LDLT had normal school achievements and physical development more than 10 years after LT. In their experience, four of six recipients who showed growth retardation with low body weights reached average heights and body weights for their ages after LDLT. Biliary stenosis was the most significant prognostic factor in terms of QOL because of the need of frequent hospital readmissions ${ }^{(25)}$.

Noma et al. ${ }^{(24)}$ evaluated the psychosocial state of 40 recipients three to 5 years after LDLT. They indicated that the recipients had a decline of psychosocial QOL due to the incapacity to return to full time work after the transplant and because of the guilty feelings to the donors after the transplantation. The authors concluded that the main predictor of psychosocial states of the recipients was the length of wait for LDLT $^{(24)}$.

The reasons for the lower mental health rate in transplanted patients observed in our report as well as in other studies may be multifold. Presence of comorbidities and complications, immunosuppressors' side-effects, and recurrence of liver disease may play an important role ${ }^{(31)}$. In our study, the presence of acute post-transplant complications was one of the factors that contributed to this decrease. Some recipients of living donors report distress because living organs were donated by healthy donors. In a systematic review, Thys et al. ${ }^{(32)}$ reported that although pediatric recipients of LDLT had improved coping skills and satisfactory peer relationships, they also had anxiety, depressive symptoms, and negative body image, and were concerned about the future. Psychological problems were sometimes induced by feelings of guilt and indebtedness toward the donor ${ }^{(33)}$.

Our finding of lower mental health in patients with more than a decade of LDLT has important clinical application. Transplanted patients should have routine psychological evaluation and therapeutic measures instituted when mental health changes are recognized. A multidisciplinary approach with psychological treatment and social intervention may be helpful for rehabilitating these patients ${ }^{(34-38)}$. The major strength of our study is that the study was limited to recipients with more than 10 years of survival after LDLT. In addition, almost all living patients participated of the study.

The major limitation of our study is the retrospective evaluation of the data and the small number of patients. This is minimized because all medical and surgical procedures were coordinated and supervised by the same transplant team and the data were retrieved from electronic medical records and study protocols. The drastic reduction of LDLT worldwide in the last decades limits the possibility to perform studies with large number of LDLT in a single institution. Multicenter studies may overcome this limitation. Prospective study and QOL comparison between deceased liver transplant and LDLT may also provide valuable contribution to this important subject.

It is concluded that long-term QOL in recipients of LDLT is similar that of general population, except for mental health domain which is reduced.

\section{Authors' contribution}

Nogueira IR: protocol development; data collection; writing of the manuscript. Coelho JCU: protocol development; interpretation of data; writing of the manuscript. Domingos MF: data collection; approval of the final version of the manuscript. Parolin MB: data collection; revision of the manuscript. Matias JEF, Freitas ACT: data interpretation; approval of the final version of the manuscript. Martins EL: analysis of data; drafting of the manuscript. Costa MAR: analysis and interpretation of data.

\section{Orcid}

Isabel Roldo Nogueira: 0000-0002-0731-1413.

Julio Cezar Uili Coelho: 0000-0002-7622-8592.

Micheli Fortunato Domingos: 0000-0001-5577-2209.

Mônica Beatriz Parolin: 0000-0002-1255-7717.

Jorge Eduardo Fouto Matias: 0000-0001-6377-8870.

Alexandre Coutinho Teixeira de Freitas: 0000-0003-4864-4940.

Eduardo Lopes Martins: 0000-0002-3360-4893.

Marco Aurélio Raeder da Costa: 0000-0002-3452-2398.

Nogueira IR, Coelho JCU, Domingos MF, Parolin MB, Matias JEF, Freitas ACT, Martins EL, Costa MAR. Boa qualidade de vida após mais de uma década de transplante hepático inter-vivos. Arq Gastroenterol. 2021;58(1):10-6.

RESUMO - Contexto - Receptores de transplante hepático inter-vivo (THIV) apresentam elevada taxa de complicações biliares e vasculares pós-operatórias que podem reduzir a qualidade de vida $(\mathrm{QV})$ devido à necessidade de tratamentos invasivos e repetitivos. Objetivo - O objetivo deste estudo é avaliar os vários aspectos da qualidade de vida dos pacientes submetidos a THIV após 10 anos de transplante e identificar possíveis fatores que possam estar associados à diminuição da QV. Métodos - Os dados de todos os pacientes com mais de 10 anos de THIV foram avaliados retrospectivamente. Os pacientes foram entrevistados por meio de um questionário de qualidade de vida (SF-36). Resultados - Do total de 440 transplantes hepáticos realizados em 17 anos (setembro de 1991 a dezembro de 2008), 78 pacientes foram submetidos a THIV, dos quais 27 estavam vivos e 25 responderam completamente ao questionário. Destes, 17 (68\%) homens e $8(32 \%)$ mulheres, com idade média de 38,6 $\pm 18,5$ anos no momento do transplante e tempo médio de acompanhamento de 15,1 $\pm 1,9$ anos. O MELD médio foi de 16,4 $\pm 4,9$ e a principal indicação para o transplante hepático foi cirrose hepática causada pelo vírus da hepatite B, 32\%. Quando comparado com a população geral, os pacientes submetidos a THIV apresentaram menor escore de saúde mental (66,4 vs 74,5; $P=0,0093)$ e escores mais altos de vitalidade ( 87,8 vs 71,$9 ; P<0,001)$, aspectos funcionais $(94,6$ vs 75,$5 ; P=0,002)$, aspectos sociais ( 93 vs 83,$9 ; P=0,005)$, aspectos físicos ( 92 vs 77,$5 ; P=0,006)$, e aspectos emocionais $(97,33$ vs 81,$7 ; P<0,001)$. Os escores do estado geral de saúde ( 73,28 vs 70,$2 ; P=0,074)$ e de dor $(78,72$ vs 76,$7 ; P=0,672)$ eram similares nos dois grupos. Conclusão-Conclui-se que os vários aspectos da QV dos receptores de transplante hepático inter-vivo são semelhantes aos da população geral mais de uma década após o transplante, exceto o domínio da saúde mental que é menor.

DESCRITORES - Transplante de fígado. Doadores vivos. Cirrose hepática. Qualidade de vida. 


\section{REFERENCES}

1. Raia S, Nery JR, Mies S. Liver transplantation from liver donors. Lancet 1989;2:497.

2. Yamaoka Y, Washida M, Honda K, Tanaka K, Mori K, Shimahara Y, et al Liver transplantation using a right lobe graft from a living related donor. Transplantation. 1994;57:1127-30.

3. Ogiso S, Kamei H, Onishi Y, Kurata N, Jobara K, Kawashima H, et al. Decreased long-term graft survival in persistent biliary complications after right-lobe living-donor liver transplantation. Clin Transplant. 2020;34:e13771.

4. Coelho JCU, Leite LO, Molena A, Freitas ACT, Matias JEF. Biliary complications after liver transplantation. Arq Bras Cir Dig. 2017;30:127-31.

5. El-Meteini M, Montasser IF, El Gendy E, Dabbous H, Hashem RE, William $\mathrm{P}$, et al. Assessment of health-related quality of life in Egyptian HCV-infected recipients after living donor liver transplantation. J Dig Dis. 2015;16:675-82.

6. Onghena L, Develtere W, Poppe C, Geerts A, Troisi R, Vanlander A, et al. Quality of life after liver transplantation: State of the art. World J Hepatol. 2016;8: 749-56.

7. Ciconelli RM, Ferraz MB, Santos W, Meinão I, Quaresma MR. Tradução para a língua portuguesa e validação do questionário genérico de avaliação de qualidade de vida SF-36 (Brasil SF-36). Rev Bras Reumatol. 1999;39:143-50.

8. Ware JE, Sherbourne CD. The MOS 36-item short-form health survey (SF-36) I. Conceptual framework and item selection. Med Care. 1992;30:473-83.

9. Laguardia J, Campos MR, Travassos C, Najar AL, Anjos LA, Vasconcellos MM Dados normativos brasileiros do questionário Short Form-36 versão 2. Rev Bras Epidemiol. 2013;16:889-97.

10. Cruz LN, Fleck MPA, Oliveira MR, Camey SA, Hoffmann JF, Bagattini AM, et al. Health-related quality of life in Brazil: normative data for the SF-36 in general population sample in the south of the country. Cien Saude Colet. 2013;18: 1911-21.

11. Desai R, Jamieson NV, Gimson AE, Watson CJ, Gibbs P, Bradley JA, et al. Quality of life up to 30 years following liver transplantation. Liver Transpl. 2008;14:1473-9.

12. Sullivan KM, Radosevich DM, Lake JR. Health-related quality of life: Two decades after liver transplantation. Liver Transpl. 2014;20:649-54.

13. Belle SH, Porayko MK, Hoofnagle JH, Lake JR, Zetterman RK. Changes in quality of life after liver transplantation among adults. National Institute of Diabetes and Digestive and Kidney Diseases (NIDDK) Liver Transplantation Database (LTD). Liver Transpl Surg. 1997;3:93-104.

14. Duffy JP, Kao K, Ko CY, Farmer DG, McDiarmid SV, Hong JC, et al. Longterm patient outcome and quality of life after liver transplantation: analysis of 20-year survivors. Ann Surg. 2010;252:652-61.

15. Coelho JC, Parolin MB, Baretta GAP, Pimentel SK, Freitas ACT, Colman D. Donor quality of life after living donor liver transplantation. Arq Gastroenterol 2005;42:83-8

16. Benzing C, Schmelzle M, Oellinger R, Gruettner K, Muehlisch AK, Raschzok $\mathrm{N}$, et al. Living-Donor Liver Transplant: An Analysis of Postoperative Outcome and Health-Related Quality of Life in Liver Donors. Exp Clin Transplant. 2018;16:568-74

17. Coelho JCU, Freitas ACT, Matias JEF, Godoy JL, Zeni Neto C, Parolin MB, et al. Donor complications including the report of one death in right-lobe living donor liver transplantation. Dig Surg. 2007;24:191-6.

18. Kikuchi R, Mizuta K, Urahashi T, Sanada Y, Yamada N, Onuma E, et al. Quality of life after living donor liver transplant for biliary atresia in Japan. Pediatr Int. 2018;60:183-90

19. Miller CM, Quintini C, Dhawan A, Durand F, Heimbach JK, Kim-Schluger $\mathrm{HL}$, et al. The International Liver Transplantation Society Living Donor Liver Transplant Recipient Guideline. Transplantation. 2017;101:938-44.
20. Abu-Gazala S, Olthoff KM. Status of adult living donor liver transplantation in the United States: Results from the adult-to-adult living donor liver transplantation cohort study. Gastroenterol Clin North Am. 2018;47:297-311.

21. Samstein B, Smith AR, Freise CE, Zimmerman MA, Baker T, Olthoff KM, et al. Complications and their resolution in recipients of deceased and living donor liver transplants: findings from the A2ALL Cohort Study. Am J Transplant. 2016;16:594-602

22. Miyagi S, Kakizaki Y, Shimizu K, Miyazawa K, Nakanishi W, Hara Y, et al Arterial and biliary complications after living donor liver transplantation: a single-center retrospective study and literature review. Surg Today. 2018;48:131-9.

23. Umeshita K, Inomata Y, Furukawa H, Kasahara M, Kawasaki S, Kobayashi E, at al. Liver transplantation in Japan: Registry by the Japanese Liver Transplantation Society. Hepatol Res. 2016;46:1171-86.

24. Noma S, Hayashi A, Uehara M, Uemoto S, Murai T. Comparison between psychosocial long-term outcomes of recipients and donors after adult-to adult living donor liver transplantation. Clin Transplant. 2011;25:714-20.

25. Kawagishi N, Takeda I, Miyagi S, Satoh K, Akamatsu Y, Sekiguchi S, et al Quality of life and problems affecting recipients more than 10 years after living donor liver transplantation. Transplant Proc. 2009;41:236-7.

26. The World Health Organisation quality of life assessment (WHOQOL) Position paper from the World Health Organization. Soc Sci Med. 1995;41:1403-9.

27. Yang LS, Shan LL, Saxena A, Morris DL. Liver transplantation: A systematic review of long-term quality of life. Liver Int. 2014;34:1298-313.

28. Bownik H, Saab S. Health-Related Quality of Life After Liver Transplantation for Adult Recipients. Liver Transpl. 2009;15:S42-S9.

29. Coelho JCU, Freitas ACD, Matias JEF, Pissaia Jr A, Godoy JL, Zeni JOV. Sexual dysfunction in males with end-stage liver disease: partial recovery after liver transplantation. J Liver: Dis Transplant. 2014;3:1-4.

30. Parolin MB, Rabinovitch I, Urbanetz AA, Scheidemantel C, Cat ML, Coelho JCU. Impact of successful liver transplantation on reproductive function and sexuality in women with advanced liver disease. Transplant Proc. 2004;36:943-4

31. Pérez-San-Gregorio MA, Martín-Rodríguez A, Domínguez-Cabello E, Férnandez-Jiménez E, Borda-Más M, Bernardos-Rodríguez A. Mental health and quality of life in liver transplant and cirrhotic patients with various etiologies. Int J Clin Health Psychol. 2012;12:203-18.

32. Thys K, Schwering KL, Siebelink M, Dobbels F, Borry P, Schotsmans P, et al Psychosocial impact of pediatric living-donor kidney and liver transplantation on recipients, donors, and the family: a systematic review. Transpl Int. 2015;28:270-80.

33. Shizuku M, Kamei H, Kimura H, Kurata N, Jobara K, Yoshizawa A, et al. Clinica features and long-term outcomes of living donors of liver transplantation who developed psychiatric disorders. Ann Transplant. 2020;25:e918500.

34. Miller LR, Paulson D, Eshelman A, Bugenski M, Brown KA, Moonka D, et al. Mental health affects the quality of life and recovery after liver transplantation. Liver Transpl. 2013;19:1272-8.

35. Grover S, Sarkar S. Liver transplant-psychiatric and psychosocial aspects. J Clin Exp Hepatol. 2012;2:382-92.

36. Pérez-San-Gregorio MÁ, Martín-Rodríguez A, Borda-Mas M, Avargues-Navarro ML, Pérez-Bernal J, Conrad E, et al. Post-traumatic growth and its relationship to quality of life up to 9 years after liver transplantation: a cross-sectional study in Spain. BMJ Open. 2017;7:e017455.

37. Dąbrowska-Bender M, Kozaczuk A, Pączek L, Milkiewicz P, Słoniewski R, Staniszewska A. Patient quality of life after liver transplantation in terms of emotional problems and the impact of sociodemographic factors. Transplant Proc. 2018;50:2031-8.

38. Dunn MA, Rogal SS, Duarte-Rojo A, Lai JC. Physical function, physical activity, and quality of life after liver transplantation. Liver Transpl. 2010;26:702-8. 